\title{
Erratum to: Breast Cancer Clinical Characteristics and Outcomes in Trinidad and Tobago
}

\author{
Marlene Camacho-Rivera $\cdot$ Camille Ragin • \\ Veronica Roach • Tricia Kalwar • Emanuela Taioli
}

Published online: 22 April 2014

(c) Springer Science+Business Media New York 2014

\section{Erratum to: J Immigrant Minority Health \\ DOI 10.1007/s10903-013-9930-5}

The original version of this article unfortunately contained a mistake, in the last sentence within the Study Settings and Participants section of the Methods.

The text should read:

The SUNY University Integrated Internal Review Board approved the study; a waiver to obtain informed consent was approved for this research, and HIPAA authorizations were waived for all subjects.

The online version of the original article can be found under doi:10.1007/s10903-013-9930-5.

M. Camacho-Rivera · T. Kalwar · E. Taioli $(\bowtie)$

Hofstra North Shore-LIJ School of Medicine, North Shore/LIJ Health System, 175 Community Drive, Rm 203, Great Neck, NY 11021, USA

e-mail: etaioli@nshs.edu

M. Camacho-Rivera $\cdot$ E. Taioli

The Feinstein Institute for Medical Research, North Shore/LIJ Health System, 350 Community Drive, Manhasset, NY 11030, USA

C. Ragin Cancer Prevention and Control Program, Fox Chase Cancer Center, Temple University Health System, Philadelphia, PA, USA

V. Roach

Trinidad and Tobago Cancer Registry, Mount Hope, Trinidad and Tobago 